\title{
Duration of effectiveness of Botulinum toxin type $A$ in excessive gingival display: a systematic review and meta-analysis
}

Taísa Figueiredo CHAGAS $^{(a)}$ Natalia Valli de ALMEIDA(a) Cinthia Oliveira LISBOA ${ }^{(a)}$ Daniele Masterson Tavares Pereira FERREIRA ${ }^{(b)}$ Claudia Trindade MATTOS(a) José Nelson MUCHA(a)

(a) Universidade Federal Fluminense - UFF, Department of Orthodontics, Niterói, RJ, Brazil.

(b) Universidade Federal do Rio de Janeiro UFRJ, Library of Health Science Center, Rio de Janeiro, RJ, Brazil.
Declaration of Interest: The authors certify that they have no commercial or associative interest that represents a conflict of interest in connection with the manuscript.

\section{Corresponding Author:}

Claudia Trindade Mattos

E-mail: claudiatrindademattos@gmail.com

ht1ps://doi.org/10.1590/1807-3107bor-2018.vol32.0030

Submitted: September 15, 2017

Accepted for publication: January 29, 2018

Last revision: March 08, 2018

\begin{abstract}
Botulinum toxin type A is effective in reducing excessive gingival display caused by hyperfunctional upper lip elevator muscles; however, this effect is transient. This study aimed to determine the duration of the effectiveness of botulinum toxin type A on a gummy smile. A systematic search was conducted using Medline (PubMed), Scopus, and Web of Science electronic databases, from 1970 to March 2017 with no language restriction; the search included studies evaluating adult patients with excessive gingival display who were treated with botulinum toxin and were followed-up for at least 3 months. OpenGrey and Clinical Trial Registry were also consulted. Quality assessment was applied to determine the level of evidence and bias, and a meta-analysis was performed. Of 2181 full texts, 71 were obtained, with 3 prospective studies meeting the selection criteria. The gingival display was significantly reduced to baseline with 2,4 , and 8 weeks of treatment. The gingival display considerably reduced at the baseline-2-week comparison $(-4.44 \mathrm{~mm}$ using raw data and $-4.05 \mathrm{~mm}$ using the standard difference) and increased throughout the weeks of follow-up. There is scant evidence to determine the duration of the effectiveness of toxin type A on a gummy smile. The effect tends to be stable until at least 8 weeks of followup, and the gingival exposure may not return to baseline within 12 weeks of follow-up. Well-designed randomized clinical trials with a minimum of 6 months of follow-up are necessary to strengthen the evidence.
\end{abstract}

Keywords: Gingiva; Botulinum Toxins, Type A; Orthodontics.

\section{Introduction}

A pleasant smile is important for socialization, because one conveys a sense of joy through facial expressions. In an agreeable smile, the border of the upper lip must be symmetrically arrayed over up to $3 \mathrm{~mm}$ of gingiva, and the gingiva line must follow the contour of the upper lip exposure. Displaying more than $3 \mathrm{~mm}$ of gingiva on smiling is called "gummy smile" and is therefore considered an aesthetic disorder. ${ }^{1}$

Gummy smile etiology may involve lip activity (excessive muscle contraction), lip length, clinical crown length, alveolar extrusion, dentoalveolar extrusion, and vertical maxillary excess. Therefore, diagnosis is essential to select the best possible therapy for each patient. ${ }^{2,3,4}$

Various procedures, such as gingivoplasty, orthodontic teeth intrusion, orthognathic surgery, and bone resection are available for reducing a gummy 
smile'; however, these are highly complex and costly. ${ }^{5}$ Excessive gingival display caused by a hyperactive upper lip can be corrected using lip repositions, ${ }^{6,7}$ myotomies, ${ }^{8}$ lip muscle detachments, ${ }^{9}$ and botulinum toxin type A (BTX-A) therapy. ${ }^{10,11}$ Since 1970, BTX-A therapy has been investigated for the treatment of various conditions associated with muscle contraction or pain. It is a potent biological toxin and constitutes as a therapeutic resource with increasing clinical applications. ${ }^{12}$

It is a natural protein produced by the anaerobic bacterium Clostridium botulinum, which inhibits the release of acetylcholine, a neurotransmitter responsible for the activation of muscle contraction and gland secretion. It reduces the muscle tone at the site of application. ${ }^{13}$ There are several subtypes of BTX, and BTX-A has been approved for cosmetic use due to its clinical safety and effectiveness. ${ }^{14}$ The literature has showed that the use of BTX-A has been effective in correcting gummy smile due to its straightforward and safe application, small doses, rapid initial action, low risk, and reversible effects. ${ }^{15}$

For the correction of gummy smile with BTX-A, however, it is necessary to examine the type of smile and the main muscles involved for accurate treatment application. The following are the types of treatments: corrective, when the cause of gummy smile is exclusively linked to muscle activity; adjuvant, when there is a combination of different causes and additional treatments, such as lip augmentation or orthodontic treatment, are indicated; or palliative, when surgery is recommended. ${ }^{15}$

For better results, the muscle or specific site should be taken into account, along with differences in dosage, the specific type of BTX, training, and technical accuracy. $16,17,18,19,20,21,22,23,24,25,26$

No systematic review has been published with reliable evidence regarding the duration of the effects of this treatment. Therefore, our aim was to perform a systematic review of the literature to determine the duration of the effects of BTX-A in the correction of gummy smile.

\section{Methodology}

This review report is based on the Preferred Reporting Items for Systematic Reviews and Meta-Analyses (PRISMA) statement. ${ }^{27}$ The available scientific literature was searched from 1970 to July 2016, with database alerts until March 2017, to identify articles regarding the duration of BTX-A effects in patients with a gummy smile. An electronic search was conducted using the following databases: Medline via Pubmed, Scopus, and Web of Science, without language restriction according to the strategy described in Table 1. Grey literature and Clinical Trials Registry were also consulted using www.opengrey. eu and http://www.clinical-trials.gov, respectively.

The eligibility criteria were designed to answer the research question in the PICO format as follows: In patients with excessive gingival display or gummy smile (P) who received BTX-A (I), how long do the effects last $(\mathrm{O})$ compared with the baseline $(\mathrm{C})$ ? The inclusion criteria were prospective clinical studies that included: individuals with excessive gingival display as the main complaint; minimum $3 \mathrm{~mm}$ of excessive gingival display reported in the anterior buccal region during the initial phase of treatment; a sample size of minimum 10 patients in the study group; the BTX-A dose specified; a description of the results obtained in millimeters or percentages; and a follow-up of at least three months after treatment reported. Case reports and articles that mentioned that patients had already been treated with BTX-A before the research were excluded.

After the exclusion of duplicate articles, two reviewers (TFC and NVA) read the titles and abstracts of the articles. Articles that met the inclusion criteria or in which the abstract was not clear enough for a definite decision were read in full, and their eligibility was independently determined. When there were differences in the evaluation results of the two reviewers, a third reviewer (JNM) was asked to determine the inclusion or exclusion of the study. Authors were contacted to clarify data when required. Reference lists of the included studies were screened for relevant research.

After inclusion of relevant studies, data were extracted and tabulated. In dubious cases, where the data extracted by two reviewers were conflicting, a third reviewer (JNM) was requested to settle potential disagreements in a consensus meeting. Data were grouped according to sample size, dose, measurement of interest, application site, gummy smile measurement unit (millimeters), statistical analysis, and conclusions. 
Table 1. Search strategy for each database.

\begin{tabular}{|c|c|}
\hline Databases & Search parameters \\
\hline \multirow[t]{2}{*}{ MEDLINE via Pubmed } & 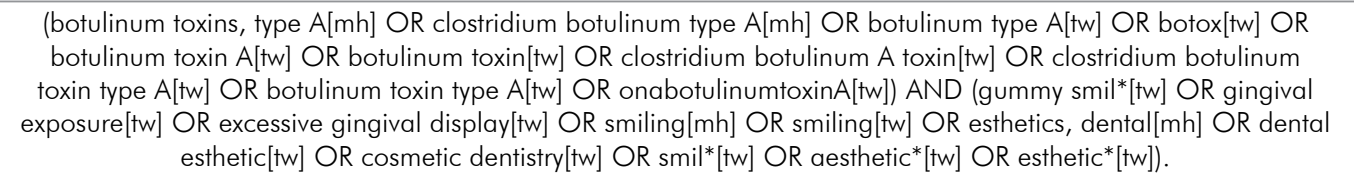 \\
\hline & Filters: Publication date from 1970/01/01 \\
\hline \multirow[t]{5}{*}{ Scopus } & $\begin{array}{c}\text { ((TITLE-ABS-KEY("botulinum type A") OR TITLE-ABS-KEY(botox) OR TITLE-ABS-KEY("botulinum toxin A") OR TITLE- } \\
\text { ABS-KEY("botulinum toxin") OR TITLE-ABS-KEY(clostridium botulinum A toxin") OR TITLE-ABS-KEY("clostridium } \\
\text { botulinum toxin type A") OR TITLE-ABS-KEY("botulinum toxin type A") OR TITLE-ABS-KEY("onabotulinumtoxina))) } \\
\text { AND ((TITLE-ABS-KEY("gummy smile") OR TITLE-ABS-KEY("gingival exposure") OR TITLE-ABS-KEY("excessive gingival } \\
\text { display") OR TITLE-ABS-KEY("smiling") OR TITLE-ABS-KEY("dental esthetic") OR TITLE-ABS-KEY ("cosmetic dentistry") } \\
\text { OR TITLE-ABS-KEY("smile") OR TITLE-ABS-KEY("aesthetic") OR TITLE-ABS-KEY("esthetic"))) }\end{array}$ \\
\hline & $\begin{array}{c}\# 1=\text { Topic }=(\text { gummy smile }) \text { OR Topic }=(\text { gingival exposure }) \text { OR Topic }=(\text { excessive gingival display }) \text { OR Topic(smiling }) \\
\text { OR Topic }=(\text { esthetics dental) OR Topic }=(\text { cosmetic dentistry }) \text { OR Topic }=(\text { smile }) \text { OR Topic=(aesthetic) OR } \\
\text { Topic }=(\text { esthetic })\end{array}$ \\
\hline & Time period $=$ All years \\
\hline & Search language $=$ English \\
\hline & $\begin{array}{l}\# 2=\text { Title }==(\text { gummy smile) OR Title }=\text { (gingival exposure) OR Title }=(\text { excessive gingival display) OR Title(smiling) } \\
\text { OR Title }=\text { (esthetics dental) OR Title }=\text { (cosmetic dentistry) OR Title }=(\text { smile) OR Title=(aesthetic) OR Title=(esthetic) }\end{array}$ \\
\hline \multirow[t]{5}{*}{ Web of Science } & $\begin{array}{c}\# 3=\text { Title }=(\text { botulinum type A) OR Title }=(\text { botox }) \text { OR Title }=(\text { botulinum toxin A) OR (botulinum toxin) OR } \\
\text { Title }=(\text { clostridium botulinum A toxin }) \text { OR Title }=(\text { clostridium botulinum toxin type A) OR Title=(botulinum toxin type } \\
\text { A) OR Title }=(\text { onabotulinumtoxin })\end{array}$ \\
\hline & 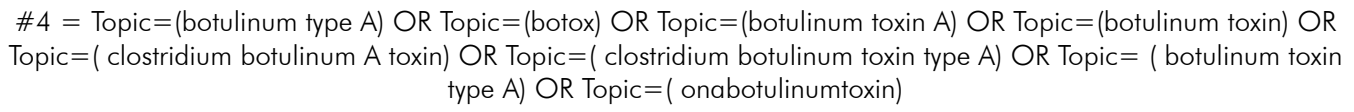 \\
\hline & $\# 5=\# 1$ OR \#2 \\
\hline & $\# 6=\# 3$ OR \#4 \\
\hline & $\# 7=\# 5$ AND \#6 \\
\hline
\end{tabular}

Both reviewers analyzed the studies using the quality assessment method reported by Fowkes and Fulton; ${ }^{28}$ this included the following characteristics: whether the study design was appropriate with respect to its objectives, sample size, and whether the research was applicable and relevant to other populations, eligibility criteria, quality of measurements (validity and reproducibility) and outcomes, completeness, and distorting influences. Blindness and the criteria regarding control group were considered "not applicable" for all articles. For evaluating the criteria for each guideline, we assigned problems for each criterion as major $(++)$, minor $(+)$, no problem $(0)$, or not applicable (NA).

To determine the risk of bias of each study, the following questions were designed using previous articles: ${ }^{28}$ "Are the results erroneously biased in a certain direction?" (with respect to bias); "Are there any serious confounding or other distorting influences?" (with respect to confounding); and "Is it likely that the results were obtained by chance?" (with respect to chance). When a major problem (++) was found in the items considered in the first or second question, the answer to that question was "Yes". When any of the previous questions were answered affirmatively, the third criterion was also answered as "Yes". Articles that obtained one or two "Yes" were considered as moderate quality, while articles that obtained all answers affirmative were classified as poor quality.

A meta-analysis was performed using the Comprehensive Meta-Analysis software (version 3.2.00089; Biostast, Inc., Englewood, USA). The mean differences of measurements in millimeters were calculated from the data in two included articles and compared between baseline and subsequent time periods $(2,4,8$, and 12 weeks) and between time intervals (baseline-2, 2-4, 4-8, and 8-12 weeks). When patients did not attend one of the follow-up appointments, their data were excluded from that comparison alone. The effect size for subgroups was presented in forest plots. Heterogeneity was tested using the $Q$-value, $I^{2}$ index, and Tau. ${ }^{2}$ 


\section{Results}

A PRISMA flow diagram of the study selection process is shown in Figure 1. The established search strategy retrieved 2,181 articles. After excluding repetitious articles, 1,480 remained. All titles and abstracts were read, and those unrelated to the review were excluded. Two articles eligible for inclusion were found in the Clinical Trials Registry; nevertheless, they were in the sample recruitment phase.

Seventy-one articles were completely read and evaluated according to the eligibility criteria.
Three articles ${ }^{5,16,29}$ were finally included in this systematic review (Table 2); all of them were prospective clinical trials and used BTX-A to treat gummy smile. Two articles ${ }^{5,29}$ used the same reference points and measurements to determine the amount of gingival display. All three articles analyzed the results at least 2 weeks and 12 weeks post-administration of Botox. One article ${ }^{5}$ also evaluated the measurements 24 weeks postinjection. The results gradually relapsed with time; however, they did not return to baseline even after $12^{5,16,29}$ and 24 weeks ${ }^{5}$.
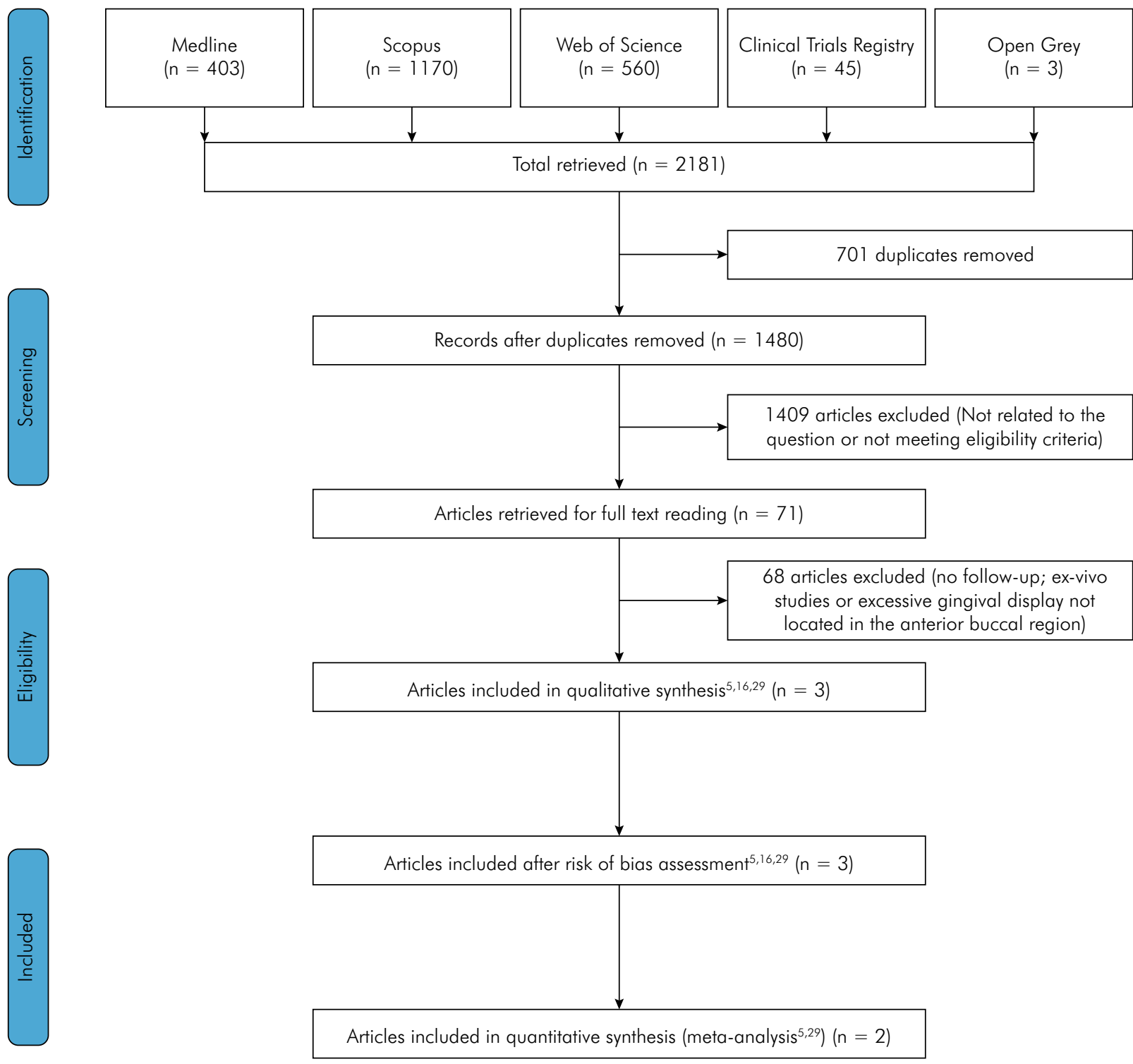

Figure 1. Flow diagram of the study selection process (PRISMA). 
Two authors were contacted via email to clarify data. One author ${ }^{16}$ did not have the required data, which was then excluded from the meta-analysis. The other author ${ }^{5}$ sent us the raw data for all times periods analyzed. Consequently, the measures from two articles ${ }^{5,29}$ were extracted to perform the meta-analysis.

The average values for each time period were compared between the two included articles ${ }^{5,29}$ (Figure 2). Heterogeneity was low for baseline (20.4\%)

Table 2. Data from the studies included.

\begin{tabular}{|c|c|c|c|c|c|c|c|c|c|c|c|c|}
\hline \multirow{2}{*}{ Author/year } & \multirow{2}{*}{$\mathrm{N} /$ Age } & \multirow{2}{*}{ Dose } & \multirow{2}{*}{ Measures } & \multirow{2}{*}{ Site } & \multicolumn{6}{|c|}{ Gummy smile/mm and SD } & \multirow{2}{*}{$\begin{array}{c}\text { Statistics } \\
\text { test }\end{array}$} & \multirow{2}{*}{ Outcomes } \\
\hline & & & & & PT & $2 w$ & $4 w$ & $8 w$ & $12 \mathrm{w}$ & $24 w$ & & \\
\hline Polo, $2008^{5}$ & $\begin{array}{c}30 \\
(F=29 \\
M=1) \\
\text { mean: } \\
24.4 \text { y }\end{array}$ & $2.5 \mathrm{U}$ & $\begin{array}{l}\mathrm{RP1} \text { to } \mathrm{RP2} \\
\mathrm{RP1} \text { to } \mathrm{RP} 3\end{array}$ & $\begin{array}{l}\text { LLSAN } \\
\text { LLS } \\
\text { Zm }\end{array}$ & $5.2 \pm 1.4$ & $0.09 \pm 1.06$ & \pm 0.73 & \pm 1.11 & \pm 1.28 & \pm 1.61 & t test & $\begin{array}{c}\text { Gingival } \\
\text { display } \\
\text { gradually } \\
\text { increased } \\
\text { from } 2 \text { weeks } \\
\text { postinjection } \\
\text { through the } \\
\text { weeks of } \\
\text { follow-up }\end{array}$ \\
\hline $\begin{array}{l}\text { Sucupira, } \\
\text { Abramovitz, } \\
2012^{16}\end{array}$ & 52 & $1.95 \mathrm{U}$ & $\begin{array}{c}\text { Gingival } \\
\text { display }\end{array}$ & LLSAN & 3.62 & 0.58 & - & - & - & - & & $\begin{array}{l}\text { In } 100 \text { percent } \\
\text { of patients, } \\
\text { resultspersisted } \\
\text { for at least } 3 \\
\text { months }\end{array}$ \\
\hline $\begin{array}{l}\text { Sanju } \\
\text { Somaiah } \\
\text { et al., } \\
2013^{29}\end{array}$ & $\begin{array}{c}10 \\
(F=8 \\
M=2) \\
(18-40 y)\end{array}$ & $2.5 U$ & $\begin{array}{l}\text { RP1 to RP2 } \\
\text { RP1 to RP3 }\end{array}$ & $\begin{array}{l}\text { LLSAN } \\
\text { LLS } \\
\text { Zm }\end{array}$ & $4.7 \pm 1.06$ & $0.95 \pm 0.72$ & $2.05 \pm 0.69$ & $2.65 \pm 0.79$ & $3.7 \pm 1.16$ & & & $\begin{array}{l}\text { There was a } \\
\text { decrease in } \\
\text { the gingival } \\
\text { display } \\
\text { (mean } \\
75.09 \%)\end{array}$ \\
\hline
\end{tabular}

RP1: median point in the lower margin of the upper lip; RP2: midpoint of the line connecting the gingival margins of maxillary central incisors; RP3: point denoting the incisal edge of the maxillary central incisor; LLSAN: left levator labii superioris alaeque nasi; LLS: levator labii superiores; and Zm: zygomaticus minor.

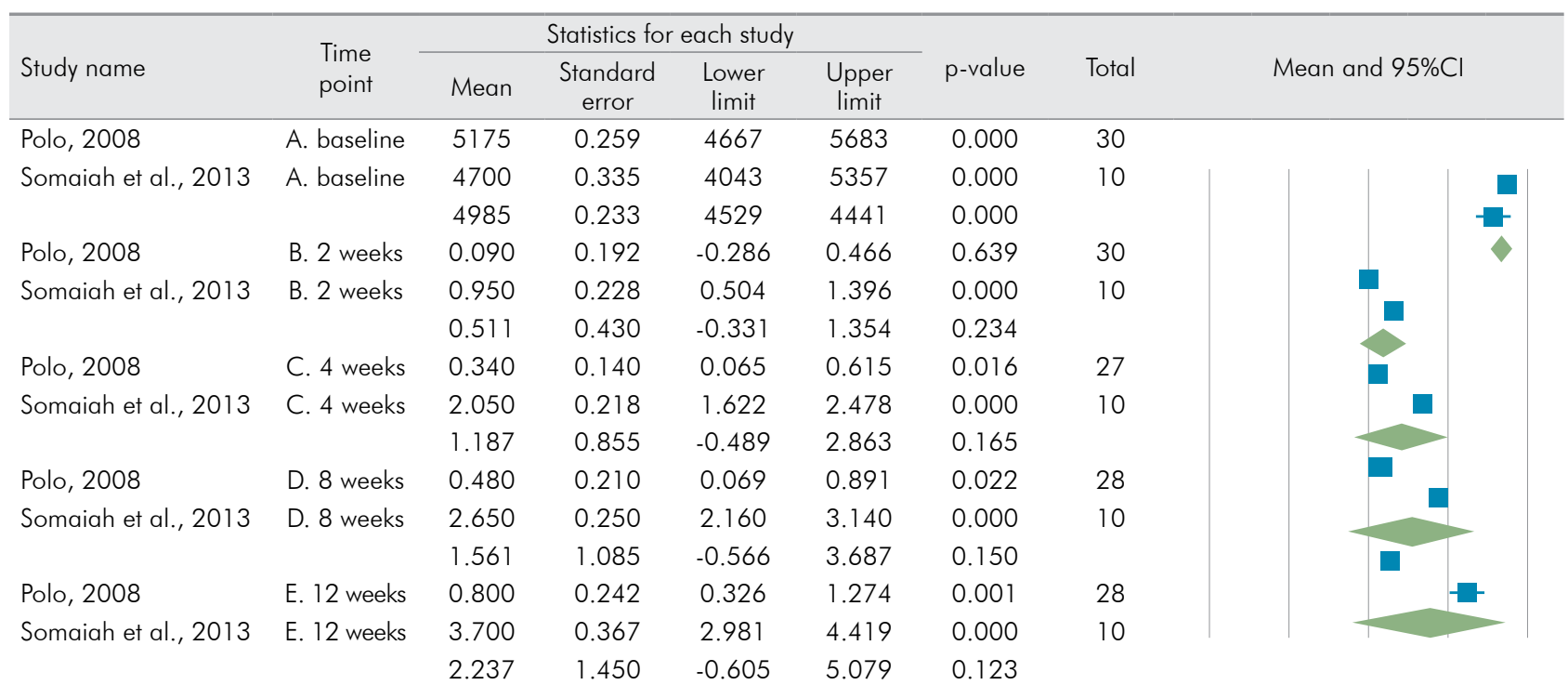

Heterogeneity (I2): baseline - 20.4\%; 2 weeks - 88\%; 4 weeks - 97.6\%; 8 weeks - 97.7\%; 12 weeks - 97.7\%

Figure 2. Comparison of average values for each time period. 
Duration of effectiveness of Botulinum toxin type A in excessive gingival display: a systematic review and meta-analysis

a)

\begin{tabular}{|c|c|c|c|c|c|c|c|c|}
\hline \multirow[b]{2}{*}{ Study name } & \multirow{2}{*}{$\begin{array}{l}\text { Time } \\
\text { point }\end{array}$} & \multicolumn{4}{|c|}{ Statistics for each study } & \multirow[b]{2}{*}{$\mathrm{p}$-value } & \multirow[b]{2}{*}{ Total } & \multirow[b]{2}{*}{ Difference in means and $95 \% \mathrm{Cl}$} \\
\hline & & $\begin{array}{c}\text { Difference } \\
\text { in means }\end{array}$ & $\begin{array}{c}\text { Standard } \\
\text { error }\end{array}$ & $\begin{array}{l}\text { Lower } \\
\text { limit }\end{array}$ & $\begin{array}{l}\text { Upper } \\
\text { limit }\end{array}$ & & & \\
\hline Polo, 2008 & A. 2 weeks & -5.110 & 0.229 & -5.559 & -4.661 & 0.000 & 30 & \\
\hline \multirow[t]{2}{*}{ Somaiah et al., 2013} & A. 2 weeks & -3.750 & 0.296 & -4.331 & -3.169 & 0.000 & 10 & \\
\hline & & -4.443 & 0.680 & -5.776 & -3.110 & 0.000 & & \\
\hline Polo, 2008 & B. 4 weeks & -4.820 & 0.240 & -5.290 & -4.350 & 0.000 & 30 & \\
\hline \multirow[t]{2}{*}{ Somaiah et al., 2013} & B. 4 weeks & -2.650 & 0.295 & -3.228 & -2.072 & 0.000 & 10 & \\
\hline & & -3.742 & 1.085 & -5.868 & -1.615 & 0.001 & & \\
\hline Polo, 2008 & C. 8 weeks & -4.690 & 0.244 & -5.169 & -4.211 & 0.000 & 27 & \\
\hline \multirow[t]{2}{*}{ Somaiah et al., 2013} & C. 8 weeks & -2.050 & 0.302 & -2.641 & -1.459 & 0.000 & 10 & \\
\hline & & -3.376 & 1.320 & -5.963 & -0.789 & 0.011 & & \\
\hline Polo, 2008 & D. 12 weeks & -4.375 & 0.256 & -4.877 & -3.873 & 0.000 & 28 & \\
\hline \multirow[t]{2}{*}{ Somaiah et al., 2013} & D. 12 weeks & -1.000 & 0.352 & -1.690 & -0.310 & 0.005 & 10 & \\
\hline & & -2.696 & 1.687 & -6.004 & 0.611 & 0.110 & & \\
\hline
\end{tabular}

Heterogeneity (I2): 2 weeks - 92.4\%; 4 weeks - 96.9\%; 8 weeks - 97.8\%; 12 weeks - 98.3\%

$-7.00-3.500 .003 .507 .00$

b)

\begin{tabular}{|c|c|c|c|c|c|c|c|c|}
\hline \multirow[b]{2}{*}{ Study name } & \multirow{2}{*}{$\begin{array}{l}\text { Time } \\
\text { point }\end{array}$} & \multicolumn{4}{|c|}{ Statistics for each study } & \multirow[b]{2}{*}{$\mathrm{p}$-value } & \multirow[b]{2}{*}{ Total } & \multirow[b]{2}{*}{ Std diff in means and $95 \% \mathrm{Cl}$} \\
\hline & & $\begin{array}{l}\text { Std diff in } \\
\text { means }\end{array}$ & $\begin{array}{c}\text { Standard } \\
\text { error }\end{array}$ & $\begin{array}{l}\text { Lower } \\
\text { limit }\end{array}$ & $\begin{array}{l}\text { Upper } \\
\text { limit }\end{array}$ & & & \\
\hline Polo, 2008 & A. 2 weeks & -4.072 & 0.556 & -5.162 & -2.981 & 0.000 & 30 & \\
\hline \multirow[t]{2}{*}{ Somaiah et al., 2013} & A. 2 weeks & -4.000 & 0.949 & -5.860 & -2.141 & 0.000 & 10 & \\
\hline & & -4.053 & 0.480 & -4.994 & -3.113 & 0.000 & & \\
\hline Polo, 2008 & B. 4 weeks & -3.865 & 0.560 & -4.963 & -2.767 & 0.000 & 27 & \\
\hline \multirow[t]{2}{*}{ Somaiah et al., 2013} & B. 4 weeks & -2.844 & 0.710 & -4.236 & -1.452 & 0.000 & 10 & \\
\hline & & -3.448 & 0.502 & -4.432 & -2.464 & 0.000 & & \\
\hline Polo, 2008 & C. 8 weeks & -3.627 & 0.520 & -4.646 & -2.607 & 0.000 & 28 & \\
\hline \multirow[t]{2}{*}{ Somaiah et al., 2013} & C. 8 weeks & -2.149 & 0.575 & -3.276 & -1.021 & 0.000 & 10 & \\
\hline & & -2.908 & 0.739 & -4.356 & -1.460 & 0.000 & & \\
\hline Polo, 2008 & D. 12 weeks & -3.228 & 0.471 & -4.151 & -2.305 & 0.000 & 28 & \\
\hline \multirow[t]{2}{*}{ Somaiah et al., 2013} & D. 12 weeks & -0.898 & 0.375 & -1.632 & -0.164 & 0.017 & 10 & \\
\hline & & -2.045 & 1.165 & -4.328 & 0.237 & 0.079 & & \\
\hline
\end{tabular}

$-6.00-3.000 .003 .006 .00$

Heterogeneity (I2): 2 weeks - 0\%; 4 weeks - 21.5\%; 8 weeks -72.4\%; 12 weeks - 93.3\%

Figure 3. Comparisons of gingival display between baseline and at 2,4 , 8, and 12 weeks of treatment. A: Data are presented in millimeters; B: Comparison using standard differences.

and high for all other time periods (88\%-97.7\%), indicating that initial characteristics of patients from both studies were similar. Figure 3 shows the forest plots of the comparisons of gingival display between baseline and 2, 4, 8, and 12 weeks.

In Figure 3A, the outcome measure is displayed as the difference in mean values $(\mathrm{mm})$. Heterogeneity was high for all time periods $(92.4 \%-98.3 \%)$; therefore, we re-assessed the comparison using standard difference as the outcome measure (Figure 3B). Heterogeneity decreased substantially for all time periods, except for the 12-week time period compared with baseline. Although the unit of measurement of standard mean difference was different, the effect size was proportionally similar to the comparison of values in millimeters. Hence, the mean difference 
a)

\begin{tabular}{|c|c|c|c|c|c|c|c|c|}
\hline \multirow[b]{2}{*}{ Study name } & \multirow{2}{*}{$\begin{array}{l}\text { Time } \\
\text { point }\end{array}$} & \multicolumn{4}{|c|}{ Statistics for each study } & \multirow[b]{2}{*}{$\mathrm{p}$-value } & \multirow[b]{2}{*}{ Total } & \multirow[b]{2}{*}{ Difference in means and $95 \% \mathrm{Cl}$} \\
\hline & & $\begin{array}{l}\text { Difference } \\
\text { in means }\end{array}$ & $\begin{array}{c}\text { Standard } \\
\text { error }\end{array}$ & $\begin{array}{l}\text { Lower } \\
\text { limit }\end{array}$ & $\begin{array}{l}\text { Upper } \\
\text { limit }\end{array}$ & & & \\
\hline Polo, 2008 & A. baseline - 2 weeks & -5.110 & 0.229 & -5.559 & -4.661 & 0.000 & 30 & \\
\hline \multirow[t]{2}{*}{ Somaiah et al., 2013} & A. baseline - 2 weeks & -3.750 & 0.296 & -4.331 & -3.169 & 0.000 & 10 & \\
\hline & & -4.443 & 0.680 & -5.776 & -3.110 & 0.000 & & \\
\hline Polo, 2008 & B. $2-4$ weeks & 0.330 & 0.181 & -0.024 & 0.684 & 0.068 & 27 & \\
\hline \multirow[t]{2}{*}{ Somaiah et al., 2013} & B. $2-4$ weeks & 1.100 & 0.223 & 0.663 & 1.537 & 0.000 & 10 & \\
\hline & & 0.704 & 0.385 & -0.050 & 1.458 & 0.067 & & \\
\hline Polo, 2008 & C. $4-8$ weeks & 0.100 & 0.187 & -0.266 & 0.466 & 0.592 & 27 & \\
\hline \multirow[t]{2}{*}{ Somaiah et al., 2013} & C. $4-8$ weeks & 0.600 & 0.236 & 0.138 & 1.062 & 0.011 & 10 & \\
\hline & & 0.329 & 0.249 & -0.159 & 0.818 & 0.186 & & \\
\hline Polo, 2008 & D. $8-12$ weeks & 0.320 & 0.228 & -0.0126 & 0.766 & 0.160 & 28 & \\
\hline \multirow[t]{2}{*}{ Somaiah et al., 2013} & D. $8-12$ weeks & 1.050 & 0.325 & 0.414 & 1.686 & 0.001 & 10 & \\
\hline & & 0.648 & 0.363 & -0.063 & 1.360 & 0.074 & & \\
\hline
\end{tabular}

$-6.00-3.000 .003 .006 .00$

Heterogeneity (I2): baseline-2weeks - 92.4\%; 2-4 weeks - 86\%; 4-8 weeks - 63.8\%; 8-12 weeks - 70.5\%

b)

\begin{tabular}{|c|c|c|c|c|c|c|c|c|}
\hline \multirow[b]{2}{*}{ Study name } & \multirow{2}{*}{$\begin{array}{l}\text { Time } \\
\text { point }\end{array}$} & \multicolumn{4}{|c|}{ Statistics for each study } & \multirow[b]{2}{*}{$\mathrm{p}$-value } & \multirow[b]{2}{*}{ Total } & \multirow[b]{2}{*}{ Difference in means and $95 \% \mathrm{Cl}$} \\
\hline & & $\begin{array}{l}\text { Difference } \\
\text { in means }\end{array}$ & $\begin{array}{l}\text { Standard } \\
\text { error }\end{array}$ & $\begin{array}{l}\text { Lower } \\
\text { limit }\end{array}$ & $\begin{array}{l}\text { Upper } \\
\text { limit }\end{array}$ & & & \\
\hline Polo, 2008 & A. baseline - 2 weeks & -4.072 & 0.556 & -5.162 & -2.981 & 0.000 & 30 & \\
\hline \multirow[t]{2}{*}{ Somaiah et al., 2013} & A. baseline - 2 weeks & -4.000 & 0.949 & -5.860 & -2.141 & 0.000 & 10 & \\
\hline & & -4.053 & 0.480 & -4.994 & -3.113 & 0.000 & & \\
\hline Polo, 2008 & B. 2-4 weeks & 0.351 & 0.198 & -0.037 & 0.740 & 0.077 & 27 & \\
\hline \multirow[t]{2}{*}{ Somaiah et al., 2013} & B. 2-4 weeks & 1.559 & 0.471 & 0.637 & 2.482 & 0.01 & 10 & \\
\hline & & 0.880 & 0.599 & -0.295 & 2.054 & 0.142 & & \\
\hline Polo, 2008 & C. 4-8 weeks & 0.103 & 0.193 & -0.275 & 0.481 & 0.593 & 27 & \\
\hline \multirow[t]{2}{*}{ Somaiah et al., 2013} & C. $4-8$ weeks & 0.805 & 0.364 & 0.092 & 1.519 & 0.027 & 10 & \\
\hline & & 0.386 & 0.344 & -0.289 & 1.062 & 0.262 & & \\
\hline Polo, 2008 & D. 8-12 weeks & 0.266 & 0.192 & -0.111 & 0.643 & 0.167 & 28 & \\
\hline \multirow[t]{2}{*}{ Somaiah et al., 2013} & D. 8-12 weeks & 1.023 & 0.390 & 0.258 & 1.788 & 0.009 & 10 & \\
\hline & & 0.568 & 0.371 & -0.159 & 1.295 & 0.126 & & \\
\hline
\end{tabular}

$-6.00-3.000 .003 .006 .00$

Heterogeneity (I2): baseline-2weeks - 0\%; 2-4 weeks - 82.1\%; 4-8 weeks - 65.5\%; 8-12 weeks - 66.9\%

Figure 4. Comparison of measurements for the following time intervals: baseline-2, 2-4, 4-8, and 8-12 weeks of treatment. A: Data are presented in millimeters; B: Comparison using standard differences.

results may be valid. The effect size (treatment effect) compared between baseline and 2, 4, and 8 weeks showed a significant decrease $(\mathrm{p}<0.05)$ in patients with gummy smile, which was greater at 2 weeks. The magnitude of this decrease reduced to almost half at 12 weeks, indicating a relapse.

Figure 4 shows the comparison of measurements for the following time intervals: baseline-2, 2-4, 4-8, and 8-12 weeks. In Figure 4A, the data are presented in millimeters. Heterogeneity was high for all time periods (63.8\%-92.4\%), and standard differences were also used to re-evaluate the comparisons (Figure 4B). Heterogeneity was null between baseline and 2-week interval, although it did not substantially decrease for other time intervals. The gingival display considerably reduced between baseline and 2-week interval (-4.44 mm using raw data, and -4.05 using standard difference) and increased with subsequent follow-ups. 
Table 3. Quality assessment of the included studies.

\begin{tabular}{|c|c|c|c|c|c|}
\hline Guideline & \multicolumn{2}{|c|}{ Checklist } & Polo 5 & $\begin{array}{l}\text { Sucupira, } \\
\text { Abramovitz } \\
\text { et al. }^{16}\end{array}$ & $\begin{array}{l}\text { Sanju } \\
\text { Somaiah } \\
\text { et al. }{ }^{29}\end{array}$ \\
\hline \multirow{5}{*}{ Study design appropriate to objective? } & Objective: & Common design: & & & \\
\hline & Prevalence & Cross sectional & - & - & - \\
\hline & Prognosis & Cohort & - & - & - \\
\hline & Treatment & Controlled trial & + & + & + \\
\hline & Cause & $\begin{array}{l}\text { Cohort, case-control, } \\
\text { cross-sectional }\end{array}$ & - & - & - \\
\hline \multirow{5}{*}{ Study sample representative? } & Source of sc & & + & - & + \\
\hline & Sampling $\mathrm{m}$ & & + & + & + \\
\hline & Sample size & & + & + & + \\
\hline & Entry criteric & & 0 & ++ & 0 \\
\hline & Non-respor & & 0 & 0 & 0 \\
\hline \multirow{4}{*}{ Control group acceptable? } & Definition o & & NA & NA & NA \\
\hline & Source of $c$ & & NA & NA & NA \\
\hline & Matching/rc & & NA & NA & NA \\
\hline & Comparabl & istics & NA & NA & NA \\
\hline \multirow{4}{*}{ Quality of measurements and outcomes? } & Validity & & 0 & 0 & 0 \\
\hline & Reproducib & & ++ & ++ & ++ \\
\hline & Blindness & & NA & NA & NA \\
\hline & Quality con & & 0 & ++ & 0 \\
\hline \multirow{4}{*}{ Completeness? } & Compliance & & 0 & ++ & 0 \\
\hline & Drop outs & & 0 & 0 & 0 \\
\hline & Deaths & & 0 & 0 & 0 \\
\hline & Missing dat & & 0 & ++ & 0 \\
\hline \multirow{5}{*}{ Distorting influences? } & Extraneous & & 0 & 0 & 0 \\
\hline & Contamina & & NA & NA & NA \\
\hline & Changes ov & & NA & NA & NA \\
\hline & Confoundin & & ++ & ++ & ++ \\
\hline & Distortion re & analysis & 0 & 0 & 0 \\
\hline \multicolumn{3}{|c|}{ "Are the results erroneously biased in a certain direction?" (with respect to bias) } & No & No & Yes \\
\hline \multicolumn{3}{|c|}{ "Are there any serious confounding or other distorting influences?" (with respect to confounding) } & Yes & Yes & Yes \\
\hline \multicolumn{3}{|c|}{ "Is it likely that the results were obtained by chance?" (with respect to chance) } & Yes & Yes & Yes \\
\hline \multicolumn{3}{|l|}{ Quality } & Moderate & Poor & Moderate \\
\hline
\end{tabular}

NA: not applicable.

The articles ${ }^{5,29}$ used the following reference points to determine the amount of gingival display: RP1, median point in the lower margin of the upper lip; $\mathrm{RP} 2$, midpoint of the line connecting the gingival margins of maxillary central incisors; and RP3, point denoting the incisal edge of the maxillary central incisor. The difference between RP1 and RP2 indicated the gingival display during smile. One study obtained the average value of before- and after-treatment measurements of gingival exposure. ${ }^{16}$

The article quality was critically appraised in accordance with a detailed checklist (Table 3). One article ${ }^{16}$ was considered as presenting poor quality.
None of the included studies explained how the sample size was determined. In $\mathrm{two}^{5,29}$ studies, the eligibility criteria were clearly described. No articles reported the intra- or/and inter-observer agreement between pre- and post-application measures. One article $^{16}$ evaluated the satisfaction of the correction of gummy smile by more than one observer.

No articles reported concern about confounding factors. The knowledge of the type of treatment (Botox application to reduce gummy smile) may have led to bias, because patients could have inadvertently changed their way of smiling for photos after Botox treatment or/and follow-up. 


\section{Discussion}

The main findings of this systematic review were that BTX-A therapy has a significant effect in reducing gingival display after application and that its results gradually decrease with time, although still satisfactorily maintained and not having returned to baseline values after 12 weeks.

There are several etiological factors associated with a gummy smile. All articles included in our review evaluated patients with gummy smile due to hyperfunctional upper lip elevator muscles, which were correctly indicated for BTX-A application, as other studies also recommend. ${ }^{4,5,10,11,12,15,16}$ Gummy smile due to skeletal vertical maxillary excess or delayed passive dental eruption should ideally be treated with surgical intervention, ${ }^{29,30}$ such as LeFort I maxillary impaction or gingivectomy, respectively. ${ }^{12}$

In two studies, ${ }^{5,29} 2.5$ units of BTX-A were injected into points of the right and left levator labii superioris alaeque nasi (LLSAN), levator labii superioris (LLS), and zygomaticus minor $(\mathrm{Zm})$ muscles. One article ${ }^{16}$ reported using 1.95 units of BTX-A for the LLSAN. Even though further studies are needed to determine an ideal dosage, injections of 2.5 units per side into LLSAN, LLS, and Zm have been considered or reported by some authors ${ }^{5,12,15,29}$ as ideal to temporarily solve gummy smile due to hyperfunctional upper lip elevator muscles.

$\mathrm{Niamtu}^{31}$ suggests that the dosage and sites of application be customized according to case severity. For example, in cases where the anterior gingival exposure is greater than $7 \mathrm{~mm}$ and concurrent with posterior gingival exposure, instead of increasing the dose of BTX-A in these muscles, the investigator increased the number of application sites from two to four in the upper lip elevator muscles and $\mathrm{Zm} .{ }^{32}$ Other investigators suggest a safer approach, with lower initial doses of toxin and retouching later if necessary ${ }_{1}^{15}$ since injection of low-dose toxin into muscle can be as effective as higher doses. ${ }^{33}$

All articles ${ }^{5,16,29}$ reported the use of frontal smiling photographs to realize the measures during all follow-up weeks and two of them ${ }^{5,29}$ described the standardization of photographs and the care taken while capturing a non-posed, spontaneous smile.
In one study, ${ }^{5}$ videos were also recorded during the first follow-up (2 weeks). Digital videos enable the analysis of the dynamic character of a smile, whereas standard digital photographs allow a visual sequence of treatment, providing a valid tool for analysis of the post-treatment smile. ${ }^{34}$

No articles reported confounding factors. It is noteworthy that once the patients are notified that the therapy will produce a different smile, they may develop a tendency to smile differently. This fact afflicts all researchers, as it constitutes a variable that cannot be controlled. ${ }^{19}$

All articles analyzed the gingival display for the first time at 2 weeks post-injection, because maximum effect occurs approximately 2 weeks after Botox application. ${ }^{12}$ The decrease in gingival exposure varied from $3.04 \mathrm{~mm}$ to $5.11 \mathrm{~mm}$ in the included studies at 2 weeks post-injection.

Although more application points were used in some patients due to greater severity, increasing the number of injection points per side did not improve aesthetic results. ${ }^{11}$ The results can differ, because they are dependent on individual characteristics. Also, various applications of BTX may lead to a permanent decrease in the capacity of muscular contraction, even if the toxin effects disappear, ${ }^{11}$ which may contribute to the difference in results.

The result of the measurements from baseline to 2 weeks was statistically significant for mean difference and standardized mean difference (Figure 4). During other follow-up intervals (2-4, 4-8, and 8-12 weeks), the mean difference and standardized mean difference were not statistically significant.

Only one study ${ }^{5}$ also evaluated the gingival display at 16, 20, and 24 weeks post-injection. At 24 weeks, the average gingival display was approximately 2.9 $\mathrm{mm}$, although the results did not return to baseline measurements $(5.2 \pm 1.4 \mathrm{~mm})$. Furthermore, based on the post-injection data for all weeks, it was speculated using a third-order polynominal that the return to the baseline average would not be achieved until 30-32 weeks post-treatment.

Our comparison through the meta-analysis showed that the average values of gingival display were similar between the two studies at baseline $\left(I^{2}, 20.4 \%\right)$, whereas high heterogeneity was observed during 
subsequent follow-up weeks. The gingival exposure did not return to baseline even at 12-week follow-up (Figure 2). A statistically significant decrease in gummy smile was observed from baseline to 2, 4, and 8 weeks using mean and standardized mean data, showing that the results of treatment may be significant for at least 8 weeks.

In one study, ${ }^{16}$ authors claim that the results persisted for at least 12 weeks in $100 \%$ of patients. Furthermore, three clinicians evaluated the results at 12 weeks postinjection using a scale of satisfaction (0-10 points). Average satisfaction was close to 10 for all observers (9.7, 9.5, and 9.9). However, only before and after treatment measurements were presented in the article and, although we contacted the authors for data from the 12-week follow-up, they were unable to send us that information. The results from this single study were unique and contrary to our meta-analysis, which showed a tendency for a decrease in the beneficial effects along the weeks following treatment.

These results should be considered with caution because many external factors and individual patient characteristics may influence the effects of BTX-A application. Factors, such as proper injection of the toxin into the muscle, solution concentration, individual susceptibility, and metabolic variation, may influence the longevity of BTX-A effects. Patients with oily skin and acne may not achieve considerable results and may require a more aggressive treatment, whereas those aged above 65 years may exhibit a reduced treatment response. ${ }^{31}$

\section{References}

1. Garber DA, Salama MA. The aesthetic smile: diagnosis and treatment. Periodontol 2000. 1996 Jun;11(1):18-28. https://doi.org/10.1111/j.1600-0757.1996.tb00179.x

2. Robbins JW. Differential diagnosis and treatment of excess gingival display. Pract Periodontics Aesthet Dent. 1999 Mar;11(2):265-72.

3. Macedo AC, Nunes VH, Sardenberg C, Alto RM, Almeida RR, Jr $\mathrm{JA}$ et al. O sorriso gengival: tratamento baseado na etiologia: uma revisão de literatura. J Bras Period. 2012;22(4):36-44.

4. Gracco A, Tracey S. Botox and the gummy smile. Prog Orthod. 2010;11(1):76-82. https://doi.org/10.1016/i.pio.2010.04.004

5. Polo M. Botulinum toxin type A (Botox) for the neuromuscular correction of excessive gingival display on smiling (gummy smile).
The few articles included and the level of evidence may be considered a limitation of this review. The articles were classified as presenting moderate and poor quality in an assessment tool that already disconsiders randomization, blinding and control groups.

Therefore, our systematic review provided weak evidence to monitor the effects of BTX-A with a reasonable follow-up period. In future studies, it is advisable that the effects of such treatment be followed for at least 6 months. Despite this shortcoming, these preliminary data may provide guidance for conducting future research.

\section{Conclusion}

Scant evidence exists to determine the duration of the effect of BTX-A in excessive gingival display. A significant effect of treatment tends to be stable until at least 8 weeks of follow-up, and the gingival exposure may not return to baseline until 12 weeks. However, well-designed clinical trials with reasonable follow-up are necessary to strengthen this observation.

\section{Acknowledgments}

We thank Dr Mario Polo, from the Department of Surgery of San Jorge Children's Hospital/Plastic and Reconstructive Center in San Juan, Puerto Rico, for the willingness to send us the necessaries data for this research. We also thank Dr Eduardo Sucupira from Clinica Essendi in Rio de Janeiro, Brazil, for answering our contact in order to clarify the information presented in his article.
Am J Orthod Dentofacial Orthop. 2008 Feb;133(2):195-203.

https://doi.org/10.1016/j.ajodo.2007.04.033

6. Silva CO, Ribeiro-Júnior NV, Campos TV, Rodrigues JG,

Tatakis DN. Excessive gingival display: treatment by a modified lip repositioning technique. J Clin Periodontol. 2013 Mar;40(3):260-5. https://doi.org/10.1111/jcpe.12046

7. Gabrić Pandurić D, Blašković M, Brozović J, Sušić M. Surgical treatment of excessive gingival display using lip repositioning technique and laser gingivectomy as an alternative to orthognathic surgery. J Oral Maxillofac Surg. 2014 Feb;72(2):404.e1-11. https://doi.org/10.1016/i.joms.2013.10.016 
8. Ishida LH, Ishida LC, Ishida J, Grynglas J, Alonso N, Ferreira MC. Myotomy of the levator labii superioris muscle and lip repositioning: a combined approach for the correction of gummy smile. Plast Reconstr Surg. 2010 Sep;126(3):1014-9. https://doi.org/10.1097/PRS.0b013e3181e3b6d4

9. Litton C, Fournier P. Simple surgical correction of the gummy smile. Plast Reconstr Surg. 1979 Mar;63(3):372-3. https://doi.org/10.1097/00006534-197903000-00014

10. Al-Fouzan AF, Mokeem LS, Al-Saqat RT, Alfalah MA, Alharbi MA, Al-Samary AE. Botulinum Toxin for the Treatment of Gummv Smile. J Contemp Dent Pract. 2017 Jun;18(6):474-8. https://doi.org/10.5005/ip-journals-10024-2068 7

11. Nasr MW, Jabbour SF, Sidaoui JA, Haber RN, Kechichian EG. Botulinum toxin for the treatment of excessive gingival display: a systematic review. Aesthet Surg J. 2016 Jan;36(1):82-8. https://doi.org/10.1093/asj/sjv082

12. Polo M. Botulinum toxin type $A$ in the treatment of excessive gingival display. Am J Orthod Dentofacial Orthop. 2005 Feb;127(2):214-8. https://doi.org/10.1016/j.ajodo.2004.09.013

13. Rao LB, Sangur R, Pradeep S. Application of Botulinum toxin type $A$ : an arsenal in dentistry. Indian J Dent Res. 2011 MayJun;22(3):440-5. https://doi.org/10.4103/0970-9290.87068

14. Pontes HA, Pontes FS, Oliveira GF, Almeida HA, Guimarães DM, Cavallero FC. Uncommon foreign body reaction caused by botulinum toxin. J Craniofac Surg. 2012 Jul;23(4):e303-5. https://doi.org/10.1097/SCS.0b013e318252f3e0

15. Mazzuco R, Hexsel D. Gummy smile and botulinum toxin: a new approach based on the gingival exposure area. J Am Acad Dermatol. 2010 Dec;63(6):1042-51. https://doi.org/10.1016/j.jaad.2010.02.053

16. Sucupira E, Abramovitz A. A simplified method for smile enhancement: botulinum toxin injection for gummy smile. Plast Reconstr Surg. 2012 Sep;130(3):726-8. https://doi.org/10.1097/PRS.0b013e31825dc32f

17. Carruthers J, Glogau R, Blitzer A. Advances in facial rejuvenation: Botulinum toxin type $A$, hyaluronic acid dermal fillers, and combination therapies: consensus recommendations. Plast Reconstr Surg. 2008;121(5):5-30S. https://doi.org/10.1097/PRS.0b013e31816de8d0

18. Kane MA. Botox injections for lower facial rejuvenation. Oral Maxillofac Surg Clin North Am. 2005 Feb;17(1):41-9. https://doi.org/10.1016/i.coms.2004.09.003

19. Niamtu J 3rd. Botox injections for gummy smiles. Am J Orthod Dentofacial Orthop. 2008 Jun;133(6):782-3. https://doi.org/10.1016/i.ajodo.2008.04.007

20. Gassia V, Beylot C, Béchaux S, Michaud T. [Botulinum toxin injection techniques in the lower third and middle of the face, the neck and the décolleté: the "Nefertiti lift"]. Ann Dermatol Venereol. 2009 May;136(4 Suppl 4):S111-8. French. https://doi.org/10.1016/S0151-9638(09)74537-5
21. Matarasso A, Shafer D. Botulinum neurotoxin type $A-A B O$ (Dysport): clinical indications and practice guide. Aesthet Surg J. 2009 Nov;29(6 Suppl):S72-9. https://doi.org/10.1016/i.asj.2009.09.016

22. Atamoros FP. Botulinum toxin in the lower one third of the face. Clin Dermatol. 2003 Nov-Dec;21(6):505-12. https://doi.org/10.1016/i.clindermatol.2003.11.014

23. Carruthers J, Carruthers A. Aesthetic botulinum A toxin in the mid and lower face and neck. Dermatol Surg. 2003 May;29(5):46876. https://doi.org/10.1046/i.1524-4725.2003.29115.x

24. Dayan SH, Maas CS. Botulinum toxins for facial wrinkles: beyond glabellar lines. Facial Plast Surg Clin North Am. 2007 Feb;15(1):41-9. https://doi.org/10.1016/i.fsc.2006.12.001

25. Dastoor SF, Misch CE, Wang HL. Botulinum toxin (Botox) to enhance facial macroesthetics: a literature review. J Oral Implantol. 2007;33(3):164-71. https://doi.org/10.1563/0-835.1

26. Casas LA. Introduction to: current aesthetic use of abobotulinumtoxinA in clinical practice: an evidence-based consensus review. Aesthet Surg J. 2012 Sep;32(1 Suppl):7S. https://doi.org/10.1177/1090820X12455430

27. Moher D, Liberati A, Tetzlaff J, Altman DG; PRISMA Group. Preferred reporting items for systematic reviews and meta-analyses: the PRISMA statement. PLoS Med. 2009 Jul;6(7):e1000097. https://doi.org/10.1371/journal.pmed.1000097

28. Fowkes FG, Fulton PM. Critical appraisal of published research: introductory guidelines. BMJ. 1991 May;302(6785):1136-40. https://doi.org/10.1136/bmi.302.6785.1136P

29. Somaiah MKS, Muddaiah S, Shetty B, Vijayananda KM, Bhat $M$, Shetty PS. Effectiveness of botulinum toxin $A$, in unraveling gummy smile: a prospective clinical study. APOS Trends in Orthodontics. 2013;3(2):54-8. https://doi.org/10.4103/2321-1407.114156

30. Suber JS, Dinh TP, Prince MD, Smith PD. OnabotulinumtoxinA for the treatment of a "gummy smile". Aesthet Surg J. 2014 Mar;34(3):432-7. https://doi.org/10.1177/1090820X14527603

31. Niamtu J 3rd. Aesthetic uses of botulinum toxin A. J Oral Maxillofac Surg. 1999 Oct;57(10):1228-33. https://doi.org/10.1016/S0278-2391(99)90493-7

32. Polo M. A simplified method for smile enhancement: botulinum toxin injection for gummy smile. Plast Reconstr Surg. 2013 Jun;131(6):934e-5e. https://doi.org/10.1097/PRS.0b013e31828bd8fa

33. Garcia A, Fulton JE Jr. Cosmetic denervation of the muscles of facial expression with botulinum toxin. A dose-response study. Dermatol Surg. 1996 Jan;22(1):39-43. https://doi.org/10.1111/j.1524-4725.1996.tb00569.x

34. Schabel BJ, Baccetti T, Franchi L, McNamara JA Jr. Clinical photography vs digital video clips for the assessment of smile esthetics. Angle Orthod. 2010 Jul;80(4):490-6. https://doi.org/10.2319/052207-243.1 